\title{
Joanna Smól, Poradnictwo w prasie kobiecej drugiej połowy XX wieku. Studium genologiczne, Poznań 2018
}

\author{
Katarzyna Zagórska \\ Wydział Filologii Polskiej i Klasycznej, Uniwersytet im. Adama Mickiewicza w Poznaniu, \\ ul. Fredry 10, 61-701 Poznań, Polska; \\ e-mail: katarzyna.zagorska@amu.edu.pl
}

Publikacja Joanny Smól Poradnictwo w prasie kobiecej drugiej połowy XX wieku. Studium genologiczne ma charakter interdyscyplinarnego opracowania poświęconego dziennikarstwu poradnikowemu. Autorka sytuuje ją w obrębie badań poradoznawczych, medioznawczych i językoznawczych (Smól 2018: 11), uzasadniając tak sprofilowane zainteresowania naukowe niewypełnioną dotychczas luką, brakiem „opracowań poświęconych dziennikarskim gatunkom poradnikowym" (Smól 2018: 12). Zwraca uwagę na precyzję kluczowych pojęć; poradoznawstwo, za Alicją Kargulową (2011), odnosi do nauki o poradnictwie, jego teorii, natomiast poradnictwo traktuje jako rodzaj szeroko rozumianej działalności społecznej (bliskie radzeniu, doradzaniu, ale nie tożsame z nim). Za pomocą przebiegu procesu doradzania charakteryzuje też doradcę, uznając go za konieczną część procesu oraz radzącego się, pozostającego elementem fakultatywnym.

Pierwsza tego typu monografia łącząca nurty lingwistyczne z genologicznymi odwołuje się do obszernego materiału drugiego półwiecza XX wieku, naznaczonego przemianami społecznymi, gospodarczymi, politycznymi i kulturowymi. Autorka przy wyborze pism do analizy kierowała się kryterium czasowym, socjologicznym, funkcjonalnym i wysokością nakładu. Nieprzypadkowo wybrała cztery tytuły, reprezentowane we wszystkich dekadach wskazanych tytułową cezurą, uznane przez Zofię Sokół (1998) za najpopularniejsze czasopisma kobiece. Materiał stanowią zatem „Moda i Życie Praktyczne”, późniejsza „Kobieta i Życie”, „Przyjaciółka” oraz „Zwierciadło” i „Filipinka”.

Obszerny materiał badawczy ilustruje koncepcję charakterystyki porady dla kobiet. Autorka nie tylko analizuje gatunek jako taki, różnicuje także prasę kobiecą (popularne tytuły o wysokim nakładzie) oraz prasę dla kobiet (szersze ujęcie, prasa o tematyce kobiecej, feministycznej, mniej dostępna), zaliczając analizowane czasopisma do pierwszej kategorii. Przedstawia konteksty historyczne, zarówno $\mathrm{w}$ perspektywie prasoznawczej (historia czasopism, periodyzacja prasy 
powojennej), jak również społecznej (kształtowanie się indywidualnych gospodarstw domowych). Na rozwój piśmiennictwa kobiecego, a szczególnie fenomen porady, wpłynęly potrzeby czytelniczek, pracujących, prowadzących dom, oddalonych od rodzinnego środowiska, zatem pozbawionych możliwości bezpośredniego radzenia się. $\mathrm{Z}$ biegiem lat porady ewoluowały adekwatnie do zmian społecznych, politycznych, a także redakcyjnych. Badaczka dostrzega liczne niuanse, które systematyzuje, wpisując w model genologiczny, podporządkowując mu tematykę i zaskakujące często, już nieco zapomniane, treści. Struktura pracy pozostaje zwięzła, logiczna i spójna.

Obszerny wstęp zawiera wspomniane wprowadzenie terminologiczne (Poradnictwo w oświetleniu poradoznawczym), charakterystykę prasy kobiecej oraz materiału badawczego z krótką prezentacją każdego z czterech analizowanych czasopism. Joanna Smól w swoich badaniach przyjmuje pojemniejsze rozumienie porady niż Władysław Tyrański (1981), dzięki czemu opracowanie zyskuje „,szersze spektrum analiz tekstów poradnikowych - również tych, które nie zakładają indywidualnego wymiaru komunikacji [...], a są nastawione wyłącznie na odbiór masowy" (Smól 2018: 23). Zwraca uwagę na środki językowe, od imperatywów po perswazję, ale też towarzyszącą przekazowi atmosferę, miłą, a nawet rodzinną. Rozdział I, zatytułowany Poradnictwo prasowe w perspektywie genologicznej, prezentuje m.in. źródła genologiczne, po/radę w świetle teorii aktów mowy i genrów mowy, dyskurs poradnikowy, konteksty kulturowe, wzorzec gatunkowy oraz jego warianty. Dynamika zmian gatunkowych w XX w. (Gajda 1991) umożliwia wieloaspektowe spojrzenie na badane zjawiska, a zatem autorka wyróżnia w ramach dyskursu poradnikowego inne, szczegółowe, jak popularnonaukowy, dydaktyczny oraz praktyczny. Zwraca też uwagę na ewolucję gatunkową tekstów poradnikowych: rada porada bezpośrednia (specjalistyczna) - porada pośrednia (medialna).

Rzetelnie zostały zarysowane zagadnienia teoretyczne (wstęp, rozdział I), jednak podstawę pracy stanowi część analityczna (rozdziały II-VI), poświęcona gatunkom dziennikarskim poradnikowym, dziennikarstwu poradnikowemu czy też formom gatunkowym dziennikarstwa prasowego o funkcji poradnikowej. Opracowanie cechuje uporządkowany układ oraz podobny sposób przybliżania treści, zasadniczo w każdym z rozdziałów znajduje się triada, którą tworzą analiza strukturalna, pragmatyczna i stylistyczna.

W analizowanym materiale badaczka dostrzegła różnorodność schematów gatunkowych, co znajduje odzwierciedlenie w charakterystyce pięciu gatunków. Pierwszy z nich stanowi porada stowarzyszona z listem do redakcji, wymagająca w kanonicznym modelu dwusegmentowej budowy tekstu, obejmującej zadane pytanie (list do redakcji) i odpowiedź (zwrot adresatywny, odniesienie do treści listu, porada). Autorka zwraca uwagę na dużą hybrydyczność stylistyczną oraz takie cechy stylowe, jak potoczność, obrazowość, oficjalność czy zawodowość. Podaje przykłady odpowiednich rubryk, np. Czytelnicy pisza - „Przyjaciółka” odpowiada (Smól 2018, 75); Między nami oraz Ludzie listy pisza... („Kobieta i Życie”; Smól 2018: 77); Listy Gabrieli („Filipinka”; Smól 2018: 77). 
Drugim zaprezentowanym gatunkiem są porady drobne, stanowiące najkrótszy, a zarazem najprostszy tekst poradnikowy. Badaczka określa wzorzec gatunkowy w wariantach formalnych (porady pojedyncze albo seryjne, dzieląc te ostatnie na monotematyczne i różnotematyczne), strukturę tekstu oraz akty mowy (np. pytanie, zachęta, podziękowanie). Nadawcą może być redakcja, ale też inni czytelnicy, udzielający porad na łamach czasopisma. Treść zakłada rozwiązanie jakiegoś problemu bądź opisuje działanie, a język przyjmuje cechy stylu użytkowego, wyrażającego dyrektywność. Autorka wskazuje reprezentację gatunku poradnikowego w konkretnych tytułach prasowych, zauważając, że porady drobne są rzadkie w „Filipince”, natomiast częstsze w pozostałych czasopismach. Podejmują m.in. tematykę kulinarną, np. jeżeli cytryna wyschnie, trzeba włożyć ja na noc do wody, znowu nabierze świeżości („Przyjaciółka” 24/1973, Smól 2018: 119); sól nie zwilgotnieje i nie stwardnieje, jeśli na dno solniczki wrzucimy parę ziarenek surowego ryżu („Zwierciadło” 29/1985, Smól 2018: 132).

Dyrektywną dominantę zachowuje trzeci gatunek, czyli porady instruktażowe, wymagające jednak większej zwięzłości i precyzji oraz szablonowości tekstu. Wersja kanoniczna łączy instruktaż (składniki, opis wykonania) z dziennikarską makietą (tytuł, lid). Autorka wskazuje możliwą wariantywność gatunkową, przy czym zwięzłość, „standaryzacja formy sprzyja [...] komunikatywności” (Smól 2018: 143). Opisuje wzorzec kanoniczny oraz warianty gatunkowe, pierwszemu przypisując szablonowość, pozostałym kreatywność i swobodę twórców. W poradach instruktażowych dominują formy nieosobowe, imperatywne oraz inkluzywne. Treści werbalne są wzmacnianie przez przekazy niewerbalne, jak fotografie, ilustrujące zamierzony efekt podejmowanych działań. Przykłady porad instruktażowych dotyczą fryzur, gimnastyki, rękodzieła, kulinariów, np.: Witaminy dla dziewczyny. Nie zaczynaj wiosny od wiosennego zmęczenia. Jedz pyszności bogate $w$ witaminy. Dzięki nim poczujesz się ładna, pełna energii i wesoła jak szczypiorek na wiosnę („Filipinka” 4/2000, Smól 2018: 137); czy prac domowych, np. Łatwy i pomysłowy [...] spróbujmy zmontować taki prosty stolik przedstawiony na zdjęciu, spetniajacy przede wszystkim role podręcznej biblioteczki, dostępnej z każdej strony (,Zwierciadło” 11/1981, Smól 2018: 137).

Kolejnym gatunkiem poddanym analizie jest wywiad poradnikowy, stanowiący odmianę gatunkową wywiadów prasowych, z widoczną funkcją radzenia w celu spopularyzowania wiedzy. Tematyka obejmuje przede wszystkim kwestie z zakresu urody, psychologii, medycyny oraz mody. Wywiad poradnikowy najczęściej występuje w postaci kanonicznej (pytanie dziennikarza, odpowiedź), choć zdarzają się też realizacje alternacyjne (jedno pytanie do kilku specjalistów, pytania czytelników). Porad w wywiadzie udzielają dziennikarze oraz eksperci, konstrukcja tekstu w stylu popularnonaukowym obejmuje nagłówek, wprowadzenie, biogram, część zasadniczą. Przykładowe teksty składają się z pytania i odpowiedzi, często ekspertów, np. Czy można zachować młodość? Zachować młodości na zawsze nie można, ale można ja znacznie przedtużyć. Oto, co na ten temat mówia lekarze... („Zwierciadło” 45/1969, Smól 2018: 146). 
Ostatnim omówionym gatunkiem jest artykuł poradnikowy, stanowiący odmianę artykułu publicystycznego, spokrewnionego z innymi formami poradnictwa prasowego. Typowa pozostaje formuła hybrydalna, szczególnie skomplikowana po 1990 r. (parateksty, fotografie). Segmentacja tekstu umożliwia nielinearny odbiór, wpływa na uatrakcyjnienie przekazu, a także innowacyjność strukturalną (adaptacje gatunków). Mniejszą niż w innych gatunkach rolę ma czytelnik, zasada niczo tylko percepcyjną. Częstsze niż imperatywne są formy inkluzywne. Bogactwo rejestrów stylistycznych umożliwia popularyzację wiedzy naukowej; jak też wyrażenie potoczności czy ludyczności. Artykuły poradnikowe podejmują różne tematy, np. Domowy krem przyrządzamy w ten sposób („Przyjaciółka” 40/54, Smól 2018: 171).

Monografia Joanny Smól nie tylko wypełnia lukę w literaturze genologicznej. Dzięki wnikliwości poznańskiej badaczki, bogatemu materiałowi oraz interdyscyplinarnemu ujęciu stanowi rzetelne opracowanie, łączące teorię z praktyką, podsumowujące drugie półwiecze XX wieku w wymiarze społecznym. Analiza komunikatów o charakterze poradnikowym z zakresu piśmiennictwa prasowego może być inspirującą lekturą dla badaczy różnych dyscyplin, językoznawców, medioznawców, kulturoznawców, ale także dla dziennikarzy, redaktorów, studentów oraz wszystkich zainteresowanych. Doświadczenia pandemii ptasiej i świńskiej grypy, a następnie Covid-19 spowodowały intensyfikację treści poradnikowych w mediach, a tym samym nieoczekiwany renesans tej formy gatunkowej i uniwersalizację treści prezentowanych w omawianej publikacji.

\section{Bibliografia}

Gajda S., 1991, Gatunki wypowiedzi potocznych, w: Język potoczny jako przedmiot badań językoznawczych, red. S. Gajda, A. Adamiszyn, Opole.

Kargulowa A., 2011, O teorii i praktyce poradnictwa. Odmiany poradoznawczego dyskursu. Podręcznik akademicki, Warszawa.

Sokół Z., 1998, Prasa kobieca w latach 1945-1995, Rzeszów.

Tyrański W., 1981, Poradnictwo magazynów młodzieżowych oraz kobiecych i rodzinnych, „Zeszyty Prasoznawcze”, nr 3, s. 77-82. 